\title{
Genetic Advance and Grain Yield Stability of Moroccan Durum Wheats Grown under Rainfed and Irrigated Conditions
}

\author{
Abdelali Boussakouran (D), ${ }^{1}$ Mohamed El Yamani $\mathbb{D}^{1,2}$ El Hassan Sakar ${ }^{10},{ }^{1,3}$ \\ and Yahia Rharrabti ${ }^{1}$ \\ ${ }^{1}$ Laboratory of Natural Resources and Environment, Polydisciplinary Faculty of Taza, Sidi Mohamed Ben Abdellah University, \\ B. P 1223, Taza, Morocco \\ ${ }^{2}$ Essaouira School of Technology, Cadi Ayyad University, Km 9, Route d'Agadir, BP. 383, Essaouira Al Jadida, Morocco \\ ${ }^{3}$ Department of Biology, Faculty of Sciences of Tetuan, Abdelmalek Essaâdi University, Mhannech II, Tetuan 93002, Morocco
}

Correspondence should be addressed to Abdelali Boussakouran; boussakouran@yahoo.fr

Received 28 January 2021; Revised 31 March 2021; Accepted 16 April 2021; Published 27 April 2021

Academic Editor: Brett L. Allen

Copyright ( $\odot 2021$ Abdelali Boussakouran et al. This is an open access article distributed under the Creative Commons Attribution License, which permits unrestricted use, distribution, and reproduction in any medium, provided the original work is properly cited.

\begin{abstract}
The development of high-yielding durum wheat genotypes requires the knowledge of the genetic variation for grain yield and its components. This study was performed to determine genetic gain and to evaluate the genotype $\times$ environment effect for grain yield and related traits in Moroccan durum wheat. A historical series of varieties developed during the last three decades was grown under two water regimes (rainfed and irrigated) during three growing seasons. Traits evaluated in the present work included grain yield, spikes per $\mathrm{m}^{2}$, kernels per spike, spikelets per spike, kernels per spikelet, spike length, kernel weight, plant height, harvest index, and fertile tillering. Results from ANOVA analyses revealed that grain yield and related traits were controlled to a large extent by water regime and growing season. Grain yield advance per year was estimated in $78 \mathrm{~kg} \mathrm{ha}^{-1}$ under irrigated conditions, with no significant change under rainfed ones. Overall, the results indicated that most of the yield components changed by breeding activities during the last three decades. AMMI and joint regression analyses revealed that intermediate varieties have a wide adaptation, and old varieties were specifically acclimated to water-limit environments, while modern varieties were performed only under favorable conditions.
\end{abstract}

\section{Introduction}

Durum wheat (Triticum turgidum L. var. durum) is grown on around 17 million hectares worldwide, with a total production of about 38 million tons [1]. It is cultivated mainly in North America, European Union, Northern Africa, and Australia. The Mediterranean basin is the most significant market and the large consumer of durum wheat products [2].

In Morocco, durum wheat is one of the leading cereal crops, appreciated by consumers, mainly used for the preparation of traditional foods [3]. It is sown annually on acreage of more than one million hectares, and the average grain yield during the last ten years (2008-2017) was estimated to be $1.74 t^{-1}$ [4]. However, most durum wheat growing regions are characterized by drought and fluctuating seasonal precipitation resulting in stress during anthesis and the grain filling period. Under these environments, increasing yield stability represents the main component for agricultural improvement $[5,6]$. In addition, it is difficult to develop high-yielding durum wheat genotypes for Mediterranean rainfed areas because of the high genotype $\times$ environment $(G \times E)$ interaction.

Testing genotypes in different environments across many growing seasons is highly needed to assess the extent of $G \times E$ interaction and to identify varieties with stable yield and wide adaptation. Several statistical methods have been developed for the analysis of yield stability and adaptation. These methods range from univariate parametric based on linear regression [7] to multivariate methods such as the 
AMMI analysis (additive main effects and multiplicative interaction) [8]. The models based on linear regression explained a small part of the sum of squares of $G \times E$ interaction and are unable to estimate the nonlinear response to environments [5]. In contrast, the AMMI model based on ANOVA and principal component analysis is able to characterize the main effect of genotype and environment and seems to be able to predict a large part of their interactions [9].

Genetic improvement in durum wheat grain yield has been associated with changes in plant characteristics [10]. Grain yield is often dissected in final kernel weight and the number of grains per square meter resulting from the number of spikes per unit area and the number of kernels per spike $[11,12]$. These two yield components, determined successively from double ridge to anthesis, are agronomic traits that provide an opportunity to improve grain yield under water-limited conditions [11]. Historical yield studies indicate that improving grain yield is accompanied by a rise in kernel number by unit area [13-16]. In addition, the increase in yield related to the introduction of semidwarf genes is responsible of a decrease in plant height and, hence, reduced competition between growing stems and spikes, giving larger spikes with more kernels per spike, while increasing the harvest index [17].

From 1960s onwards, wheat production has increased noticeably worldwide [18]. Evaluation of the annual rate of genetic gain within many breeding programs gives a benchmark for progress in plant breeding [19]. Previous estimates from several countries for genetic gain in durum wheat have been reported [10, 13, 20-23].

The beginning of durum wheat breeding in Morocco dates back to 1920. By 1970s, the partnership with CIMMYT and ICARDA provided opportunities to have access to a wide range of germplasm with earliness characteristics and semidwarf genes. It has helped with the development of a set of durum wheat varieties with high yield, good quality, early maturity, and drought tolerance. Therefore, it is important to perform a retrospective study in order to assess the genetic advance for Moroccan varieties as well as analyzing their stability. The current study aims to (i) investigate the water regimes effect, (ii) to quantify the genetic change in grain yield and related traits, and (iii) to analyze yield stability and adaptation for six representative Moroccan durum wheat varieties developed during the last three decades.

\section{Materials and Methods}

2.1. Experimental Site and Design. The trials were carried out under two water regimes (irrigated and rainfed) during 2017, 2018, and 2019 growing seasons in the experimental station of the Polydisciplinary Faculty of Taza, northern Morocco. Experimental conditions and agronomic details are given in Table 1 . The total rainfall and average temperatures recorded during the three growing seasons are shown in Figure 1. The study region is characterized by a Mediterranean climate with humid winters and semiarid summers. Six durum wheat varieties were selected to represent the germplasm developed in Morocco between 1984 and 2007 (Table 2).
Three periods were considered, and two varieties for each period were selected: old (developed from 1980 to 1990), intermediate (developed from 1990 to 2000), and modern (developed from 2000 to 2010). The trials were arranged in a completely randomized block design with three replicates. The varieties were planted manually in plots of three rows $2 \mathrm{~m}$ long and spaced $0.2 \mathrm{~m}$ apart. Irrigated plots were watered biweekly, and the volume of required water was determined based on the daily meteorological data and calculated as the difference between crop evapotranspiration and precipitation to replace evapotranspiration loss. On the other hand, the rainfed plots were exposed only to natural precipitation.

2.2. Measurements. At ripening before harvest, spikes per $\mathrm{m}^{2}$ were counted for each plot. Five plants were randomly chosen, and the following yield components were determined: kernels per spike, spikelets per spike, and spike length $(\mathrm{cm})$. Plant height $(\mathrm{cm})$ was measured from the soil to the base of the spike. The number of kernels per spikelet was calculated as the kernels per spike divided by spikelets per spike. Harvest index was computed as the ratio of kernel weight to the total above-ground plant weight. The whole plots were harvested manually, and grain yield $\left(\mathrm{kg} \mathrm{h}^{-1}\right)$ was determined at $10 \%$ moisture content. Fertile tillering (\%) was calculated by dividing the number of spikes containing grains by the maximum stems number, expressed as a percentage. Kernel weight $(\mathrm{mg})$ was also assessed in three samples of $100 \mathrm{~g}$ of harvested grains.

2.3. Statistical Analyses. The responses of the period of release, water regimes, growing seasons, and their interactions were tested with ANOVA. Least significant difference (LSD) values were calculated at the $5 \%$ probability level. Principal component analyses (PCA) and correlation studies were performed on the matrix from the mean data across replicates and growing seasons. Genetic gain was computed as the slope of the linear regression between the trait and the year of release. All statistical analyses were carried out by using the Statgraphics Centurion XVII package (StatPoint Technologies, Inc., Virginia, USA).

2.4. $G \times E$ Interaction Studies. Data from growing seasons and water regimes were combined as environments $(3 \times 2=6)$ to test the effect of variety, environment, and their interaction on grain yield. Each combination was considered as a specific environment and was performed based on the joint regression analysis (JRA) and the additive main effects and multiplicative interaction (AMMI) model to analyze the $G \times E$ interaction effects and estimate the adaptation pattern of our durum wheat varieties.

2.5. Joint Regression Analysis (JRA). JRA was suggested by Finlay and Wilkinson [7]. This method quantifies the interactions by modelling individual grain yield as a linear function of a continuous variable representing the effect of 
TABLE 1: Experimental conditions of the trials.

\begin{tabular}{|c|c|c|c|}
\hline & 2016-2017 & 2017-2018 & 2018-2019 \\
\hline Coordinates & & $34^{\circ} 12^{\prime} \mathrm{N} 4^{\circ} 00^{\prime} \mathrm{W}$ & \\
\hline Altitude & & $550 \mathrm{~m}$ & \\
\hline Sowing date & 14 Dec 2016 & 18 Dec 2017 & 19 Dec 2018 \\
\hline Harvest date & 21 June 2017 & 26 June 2018 & 23 June 2019 \\
\hline \multicolumn{4}{|l|}{ Soil characteristics } \\
\hline Classification & & Typic Xerofluvent & \\
\hline Texture & & Silty clay loam & \\
\hline $\mathrm{pH}$ & & 7.14 & \\
\hline $\mathrm{P}$ & & $20 \mathrm{mg} \mathrm{kg}^{-1}$ & \\
\hline $\mathrm{K}$ & & $16 \mathrm{mg} \mathrm{kg}^{-1}$ & \\
\hline Organic matter & & $2.85 \%$ & \\
\hline Sowing density & & 350 kernels $\mathrm{m}^{-2}$ & \\
\hline \multicolumn{4}{|l|}{ Fertilization } \\
\hline 1st application & & $350 \mathrm{~kg} \mathrm{ha}^{-1} \mathrm{NPK}(15: 15: 15)$ & \\
\hline 2nd application & & $200 \mathrm{~kg} \mathrm{ha}^{-1}$ ANS $26 \% \mathrm{~N}$ & \\
\hline
\end{tabular}

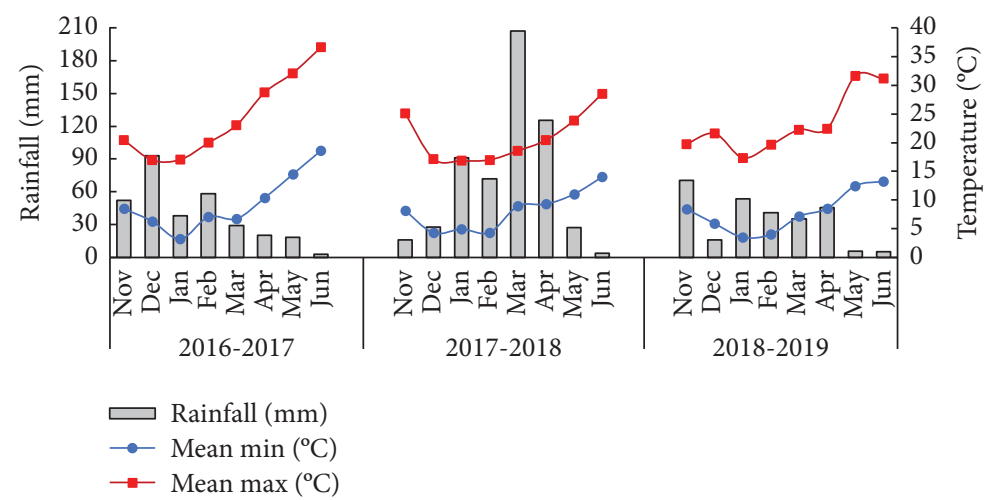

Figure 1: Rainfall distribution and average air temperatures during 2017, 2018, and 2019.

TABLE 2: Year of release and pedigree of six durum wheat varieties used in the current study.

\begin{tabular}{lccc}
\hline Variety & Year of release & Pedigree & Breeding program \\
\hline Marzak & 1984 & INRA EII, 12 selection in CIMMYT germplasm & INRA \\
Karim & 1985 & Bittern 'S“ or sel in " JO'S'.AA":S'//FG"S“" & INRA \\
Ourgh & 1995 & NRA 1769 "Unk" & INRA \\
Tarek & 1995 & INRA 1768 "Unk" & INRA \\
Marouane & 2003 & Sebou/BT40//Sarif \#CF4(1896-1904) & INRA \\
Faraj & 2007 & Cross between Nassira, Qarmal, and Lahn (ICARDA) & INRA \\
\hline
\end{tabular}

the environment. Stability parameter calculated was the regression coefficient $\left(b_{i}\right)$ :

$$
\left(\mathrm{ge}_{\mathrm{ij}}\right)=b_{i} e_{j}+d_{\mathrm{ij}}
$$

where $\mathrm{ge}_{\mathrm{ij}}$ is the effect of the interaction between the $i^{\text {th }}$ variety and $j^{\text {th }}$ environment $\left(\mathrm{e}_{j}\right), b_{i}$ is the linear regression coefficient for the $i^{\text {th }}$ variety, and $d_{\mathrm{ij}}$ is the deviation associated with the $i^{\text {th }}$ variety in the $j^{\text {th }}$ environment. According to Finlay and Wilkinson [7], regression coefficient $\left(b_{i}\right)$ close to 1.0 indicates the variety is well adapted to all environments. A regression coefficient above 1.0 indicates a variety specifically adapted to high performing environments. However, the value of regression coefficient below 1.0 indicates a variety specifically adapted to unfavorable environments. follows:

The joint regression for grain yield was calculated as

$$
\mathrm{gy}_{\mathrm{ij}}=\mu+v_{i}+b_{i} e_{j}+\varepsilon_{\mathrm{ij}} \text {, }
$$

where $\mathrm{gy}_{\mathrm{ij}}$ is the grain yield of variety $i$ in the environment $j$, $v_{i}$ is the main effect of the $i^{\text {th }}$ variety, $\mu$ is the grand mean, $b_{i}$ is the linear regression coefficient of the $i^{\text {th }}$ variety, $e_{j}$ is the main effect of the $j^{\text {th }}$ environment, and $\varepsilon_{\mathrm{ij}}$ is the residual.

2.6. AMMI Analysis. Each environment was performed based on the AMMI model [8] to explain the $G \times E$ interaction effects. The following statistical model was used:

$$
\mathrm{gy}_{\mathrm{ij}}=\mu+\alpha_{v}+\beta_{e}+\sum \lambda_{n} \cdot \Upsilon_{\mathrm{in}} \cdot \delta_{\mathrm{jn}} \cdot \rho_{\mathrm{ij}} \text {, }
$$


where $\operatorname{gy}_{i j}$ is the grain yield of variety $i$ in the environment $j$, $\alpha_{v}$ is the variety deviation from the grand mean, $\mu$ is the grand mean, $\beta_{e}$ is the environment deviation, $\lambda_{n}$ is the eigenvalue for interaction principal component $n, \Upsilon_{\text {in }}$ is the eigenvalue for variety $i$ and principal component $n, \delta_{\text {jn }}$ is the eigenvalue for environment $j$ and principal component $n$, and $\rho_{\mathrm{ij}}$ is the residual error.

The AMMI stability value (ASV) described by Purchase et al. [24] was calculated using the following formula:

$$
\mathrm{ASV}=\sqrt{\left[\frac{\mathrm{PC} 1 \text { sum of squares }}{\mathrm{PC} 2 \text { sum of squares }}(\text { score } \mathrm{PC} 1)\right]^{2}+(\text { score } \mathrm{PC} 2)^{2}},
$$

where $\mathrm{PC} 1$ and $\mathrm{PC} 2$ are the interaction principal components 1 and 2, respectively, and score PC1 and score PC2 are respective scores from the principal component analysis of the AMMI model. The yield stability index (YSI) was calculated as $\mathrm{YSI}=\mathrm{R}_{\mathrm{ASV}}+R_{\mathrm{Y}}$, where $\mathrm{R}_{\mathrm{ASV}}$ is the rank of the AMMI stability value, and RY is the rank of the mean grain yield of each variety across environments. The AMMI analysis, AMMI stability value, yield stability index, joint regression, and rank stability index were performed by using $R$ software (R Core Team, 2018) with agricolae package [25].

\section{Results}

3.1. Data Variability. The combined analyses of variance revealed highly significant effects of water regime, growing season, and period of release on all evaluated traits (Table 3). Grain yield and related traits were controlled to a large extent by water regime. The growing season effect was mainly noticed on plant height and spike length, accounting about 57 and $47 \%$ of total variance, respectively. In contrast, the magnitude of period of release was of minor importance (less than $13 \%$ of total variance), except for kernels per spikelet and spike length where it explained 25 and $35 \%$, respectively. The variance of kernels per spike, kernel weight, and fertile tillering was assigned in equal proportion to water regime and growing season. Moreover, spikelets per spike were equally affected by the period of release and growing season. Interactions among the three factors were in general of lower importance, and only water regime $\times$ period of release explained around $18 \%$ of the variability for kernels per spikelet.

3.2. Water Regime and Growing Season Effects. Mean values of the grain yield and related traits for two water regimes and three growing seasons are given in Table 4 . The results revealed that the values of all traits were significantly reduced under rainfed conditions compared with the irrigated ones. The decrease generated by water deficit was $30 \%$ in grain yield and spikes per $\mathrm{m}^{2}, 15 \%$ in harvest index, and lower than $10 \%$ in the remaining traits. In addition, grain yield and related traits varied significantly among the three growing seasons. 2018 was the wettest season for this study $(570 \mathrm{~mm})$ (Figure 1), and then, the average grain yield was
$4702 \mathrm{~kg} \mathrm{ha}^{-1}$ with the highest values for kernel weight (47.2 mg), harvest index (0.40), kernels per spikelet (2.5), fertile tillering $(67.2 \%)$, and plant height $(88.1 \mathrm{~cm}) .2017$ and 2019 were drier growing seasons $(312 \mathrm{~mm}$ and $273 \mathrm{~mm}$ of total rainfall, respectively) as compared to 2018. Consequently, the average grain yield decreased significantly (3274 and $3418 \mathrm{~kg} \mathrm{ha}^{-1}$, respectively). 2018 has received an important amount of precipitation $(570 \mathrm{~mm})$, which resulted in the greatest average grain yield $\left(4702 \mathrm{~kg} \mathrm{ha}^{-1}\right)$.

3.3. Genetic Progress. Mean comparisons among the release periods for the considered traits are given in Table 4. When combining the two-trial data, high values of grain yield, harvest index, spikelets per spike, fertile tillering, and spike length were found in modern varieties, while kernel weight, kernels per spikelet, and plant height exhibited good values in old varieties. For spikes per $\mathrm{m}^{2}$ and kernels per spike, means values were unchangeable from old to modern varieties.

Absolute and relative genetic changes in grain yield and related traits under irrigated and rainfed conditions for six durum wheat varieties are presented in Table 5. Considering all experiments (irrigated and rainfed trials), grain yield progress increased significantly between 1984 and 2007, with an annual genetic gain of $23.5 \mathrm{~kg} \mathrm{ha}^{-1}$ (data not shown). Within the irrigated trial, grain yield increased over the period between 1987 and 2007, representing a genetic gain of 1.75\% year $^{-1}$ (or $78 \mathrm{~kg} \mathrm{ha}^{-1}$ year $^{-1}$ ). Most of the yield components were positively correlated with year of release, representing a genetic advance of $0.51 \%$ year $^{-1}$ (or 2.19 spike year $^{-1}$ ) for spikes per $\mathrm{m}^{2}, 1.05 \%$ year $^{-1}$ (or $0.01 \%$ year $^{-1}$ ) for harvest index, $0.6 \%$ year $^{-1}$ (or 0.10 spikelet year $^{-1}$ ) for spikelets per spike, $0.51 \%$ year $^{-1}$ (or 0.33 fertile tillers year ${ }^{-1}$ ) for fertile tillering, and $0.47 \%$ year $^{-1}$ (or $0.03 \mathrm{~cm} \mathrm{year}^{-1}$ ) for spike length. In contrast, significant genetic loss was observed for kernels per spike with a decrease of $-0.23 \%$ year $^{-1}$ (or -0.09 kernel year $^{-1}$ ) and kernels per spikelet with loss of $-0.79 \%$ year $^{-1}$ (or -0.02 kernel year $^{-1}$ ). No significant change was observed for the kernel weight and plant height with year of release. Regarding the rainfed conditions, no significant variation for grain yield occurred between 1984 and 2007. From all yield components, three traits changed significantly over time exhibiting a genetic gain of $0.44 \%$ year $^{-1}$ (or 0.066 spikelet year $^{-1}$ ) for spikelets per spike and $0.14 \%$ year $^{-1}$ (or 0.082 fertile tillers year ${ }^{-1}$ ) for fertile tillering, $0.33 \%$ year $^{-1}$ (or $0.021 \mathrm{~cm} \mathrm{year}^{-1}$ ) for spike length. The rest of traits did not differ between 1984 and 2007.

3.4. Associations among Grain Yield and Related Traits. Correlations among grain yield and related traits are presented in Table 6 for the two trials, separately. The irrigated and rainfed conditions impacted differently the relationships among traits. In fact, under irrigated conditions, grain yield was significantly and positively related to spikes per $\mathrm{m}^{2}$ $\left(r=0.832^{*}\right)$, harvest index $\left(r=0.818^{*}\right)$, spikelets per spike $\left(r=0.814^{*}\right)$, fertile tillering $\left(r=0.912^{*}\right)$, and spike length $\left(r=0.839^{*}\right)$, while negatively associated with kernels per spikelet $\left(r=-0.815^{*}\right)$ and plant height $\left(r=-0.812^{*}\right)$. Under 


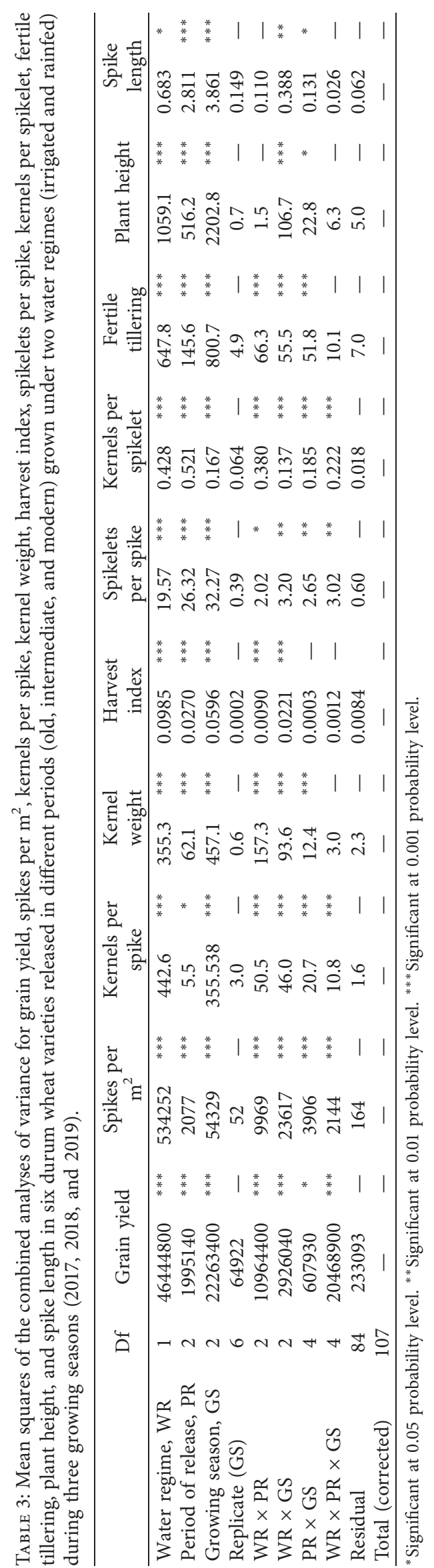




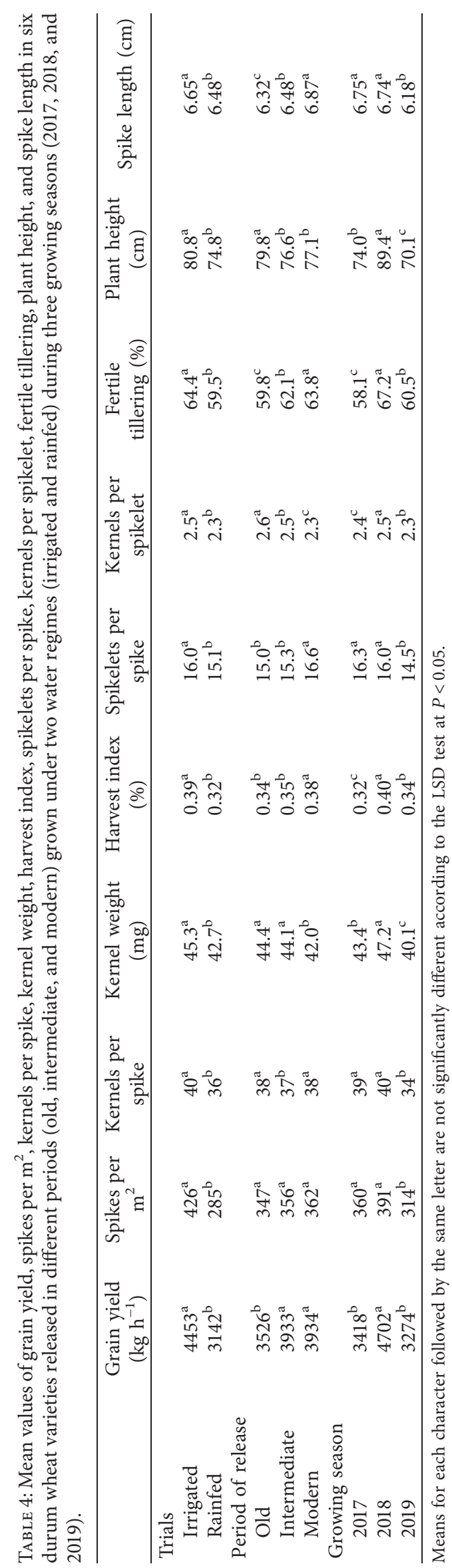


TABLE 5: Absolute and relative genetic changes in grain yield, spikes per $\mathrm{m}^{2}$, kernels per spike, kernel weight, harvest index, spikelets per spike, kernels per spikelet, fertile tillering, plant height, and spike length in six durum wheat varieties grown under two water regimes (irrigated and rainfed) during three growing seasons (2017, 2018, and 2019).

\begin{tabular}{|c|c|c|c|c|c|c|c|c|c|c|}
\hline & $\begin{array}{l}\text { Grain yield } \\
\left(\mathrm{kg} \mathrm{h}^{--1}\right)\end{array}$ & $\begin{array}{l}\text { Spikes } \\
\text { per } \mathrm{m}^{2}\end{array}$ & $\begin{array}{c}\text { Kernels } \\
\text { per spike }\end{array}$ & $\begin{array}{c}\text { Kernel } \\
\text { weight } \\
(\mathrm{mg})\end{array}$ & $\begin{array}{c}\text { Harvest } \\
\text { index (\%) }\end{array}$ & $\begin{array}{l}\text { Spikelets } \\
\text { per spike }\end{array}$ & $\begin{array}{l}\text { Kernels } \\
\text { per } \\
\text { spikelet }\end{array}$ & $\begin{array}{c}\text { Fertile } \\
\text { tillering } \\
(\%)\end{array}$ & $\begin{array}{c}\text { Plant } \\
\text { height } \\
(\mathrm{cm})\end{array}$ & $\begin{array}{l}\text { Spike } \\
\text { length } \\
(\mathrm{cm})\end{array}$ \\
\hline \multicolumn{11}{|l|}{ Irrigated } \\
\hline $\begin{array}{l}\text { Absolute } \\
\text { changes } \\
\left(\text { year }^{-1}\right)\end{array}$ & 78.08 & 2.19 & -0.09 & 0.07 & 0.01 & 0.10 & -0.02 & 0.33 & -0.04 & 0.03 \\
\hline $\begin{array}{l}\text { Relative } \\
\text { changes \% } \\
\left(\text { year }^{-1} \text { ) }\right.\end{array}$ & 1.75 & 0.51 & -0.23 & 0.16 & 1.05 & 0.60 & -0.79 & 0.51 & -0.05 & 0.47 \\
\hline$r^{2}$ & $0.85^{* *}$ & $0.93^{* *}$ & $0.81^{*}$ & 0.60 & $0.92^{* *}$ & $0.79^{*}$ & $0.86^{* *}$ & $0.93^{* *}$ & 0.03 & $0.87^{* *}$ \\
\hline \multicolumn{11}{|l|}{ Rainfed } \\
\hline $\begin{array}{l}\text { Absolute } \\
\text { changes } \\
\left(\text { year }^{-1}\right)\end{array}$ & -31.08 & -0.69 & 0.10 & -0.26 & 0.01 & 0.07 & -0.01 & 0.08 & -0.18 & 0.02 \\
\hline $\begin{array}{l}\text { Relative } \\
\text { changes \% } \\
\left(\text { year }^{-1} \text { ) }\right.\end{array}$ & -0.99 & -0.24 & 0.23 & -0.62 & 0.34 & 0.44 & -0.18 & 0.14 & -0.25 & 0.33 \\
\hline$r^{2}$ & 0.63 & 0.39 & 0.45 & 0.64 & 0.53 & $0.77^{*}$ & 0.18 & $0.29^{*}$ & 0.56 & $0.78^{*}$ \\
\hline
\end{tabular}

*Significant at 0.05 probability level. ${ }^{* *}$ Significant at 0.01 probability level.

rainfed conditions, correlation coefficients were in general less important, although some interesting associations can be highlighted. Grain yield was positively related only to spikes per $\mathrm{m}^{2}\left(r=0.960^{* *}\right)$ and kernel weight $\left(r=0.960^{* *}\right)$ but negatively associated to kernels per spike $\left(r=-0.934^{* *}\right)$ and plant height $\left(r=-0.858^{*}\right)$. In both trials, significant correlations were found among yield component, and kernels per spike were negatively related to spikes per $\mathrm{m}^{2}\left(r_{\text {irrigated }}=-0.946^{* *}\right.$; $\left.r_{\text {rainfed }}=-0.960^{* *}\right)$ and kernel weight $\left(r_{\text {irrigated }}=-0.954^{* *}\right.$; $\left.r_{\text {rainfed }}=-0.907^{*}\right)$. In addition, a negative association was scored between plant height and harvest index $\left(r_{\text {irrigated }}=-0.931^{* *} ; r_{\text {rainfed }}=-0.825^{*}\right)$.

Principal component analysis (PCA) was applied as a second tool to establish the characteristics of each group of varieties and the particularity of each trial with regard to yield components expression (Figures 2 and 3). Results showed that $84 \%$ of the total variability was accounted by the first two PCs: the PC1 explained $60 \%$ of the total variance, while PC2 accounted for $24 \%$. The first PC separated kernels per spikelet appearing in the negative direction from all other traits positioned in the positive one. The variability along the second PC was mainly due to grain yield, plant height, spikes per $\mathrm{m}^{2}$, kernels per spike, kernel weight, and kernels per spikelet located towards the upper direction, while fertile tillering, harvest index, spikelets per spike, and spike length were observed downwards. Variety means plotted on the plan determined by the two PC axes are arranged in clusters related to three groups of varieties (Figure 2) and to two trials (Figure 3). PC1 separated clearly between the both water regimes and irrigated trial located on the right side with significant scores for all traits as revealed by mean comparison. The observation of Figure 3 showed some discrimination along PC2 between groups of varieties. The cluster corresponding to old varieties was located on the positive side with higher values of kernels per spikelet and plant height, while the modern varieties were clustered in the negative side, close to the eigenvectors for grain yield, fertile tillering, harvest index, spikelets per spike, and spike length. Intermediate varieties occupied an intermediate position; this location suggests an association with better kernel weight, spikes per $\mathrm{m}^{2}$, and kernels per spike.

3.5. G $\times$ E Interactions for Grain Yield. The relationship between variety mean grain yield and regression coefficient $\left(b_{i}\right)$ is shown in Figure 4 . The varieties are distributed according to their specific adaptability. The values of $b_{i}$ across varieties ranged from 0.89 to 1.82 . Utilizing the joint regression method, "Ourgh" and "Tarek" were the most stable varieties with $b_{i}$ values closer to 1 , "Karim" and "Marzak" were specifically adapted to low-yielding environments with the lowest $b_{i}$ values, whereas the varieties "Faraj" and "Marouane" with the highest values were adapted only to high performing environments.

The additive and interaction effects of both variety and environment on grain yield are shown in Figure 5. IPCA1 of the AMMI model justify $86 \%$ of the total variation. The biplot of the IPCA1 against grain yield clustered "Ourgh" and "Tarek" near to the origin of the axes, indicating that intermediate varieties have a small grain yield variation between environments. Old varieties "Karim" and "Marzak" were located in the upper part of figure, close to the vectors representing rainfed 2019 and 2017 environments. The points corresponding to modern varieties "Faraj" and "Marouane" were placed in negative direction of the IPCA1 axis and closer to the vectors symbolizing irrigated in 2017, 2018, and 2019 environments.

The AMMI model and joint regression analysis provided no quantitative measures. AMMI stability indices were applied as an additional tool to quantify and rank varieties in terms of grain yield stability (Table 7). Based on the ASV 
TABLE 6: Correlations between analyzed traits in six durum wheat varieties released in different periods (old, intermediate, and modern) grown under two water regimes: irrigated (upper right diagonal) and rainfed (lower left diagonal) during three growing seasons (2017, 2018, and 2019).

\begin{tabular}{|c|c|c|c|c|c|c|c|c|c|c|c|c|c|c|c|c|c|c|c|c|}
\hline \multirow[b]{2}{*}{ Grain yield } & \multicolumn{2}{|c|}{$\begin{array}{l}\text { Grain } \\
\text { yield }\end{array}$} & \multicolumn{2}{|c|}{$\begin{array}{c}\text { Spikes per } \\
\mathrm{m}^{2}\end{array}$} & \multicolumn{2}{|c|}{$\begin{array}{l}\text { Kernels } \\
\text { per spike }\end{array}$} & \multicolumn{2}{|c|}{$\begin{array}{l}\text { Kernel } \\
\text { weight }\end{array}$} & \multicolumn{2}{|c|}{$\begin{array}{c}\text { Harvest } \\
\text { index }\end{array}$} & \multicolumn{2}{|c|}{$\begin{array}{l}\text { Spikelets } \\
\text { per spike }\end{array}$} & \multicolumn{2}{|c|}{$\begin{array}{c}\text { Kernels per } \\
\text { spikelet }\end{array}$} & \multicolumn{2}{|c|}{$\begin{array}{l}\text { Fertile } \\
\text { tillering }\end{array}$} & \multicolumn{2}{|c|}{$\begin{array}{l}\text { Plant } \\
\text { height }\end{array}$} & \multicolumn{2}{|c|}{$\begin{array}{l}\text { Spike } \\
\text { length }\end{array}$} \\
\hline & - & - & 0.832 & $*$ & -0.714 & - & 0.583 & - & 0.818 & $*$ & 0.814 & $*$ & -0.815 & $*$ & 0.912 & $*$ & -0.812 & $*$ & 0.839 & $*$ \\
\hline $\begin{array}{l}\text { Spikes per } \\
\mathrm{m}^{2}\end{array}$ & 0.960 & $* *$ & - & - & -0.946 & ** & 0.811 & - & 0.993 & $* * *$ & 0.943 & $* *$ & & $* * *$ & 0.907 & * & -0.898 & * & 0.945 & $* *$ \\
\hline $\begin{array}{l}\text { ernels } \\
\text { er spike }\end{array}$ & -0.934 & $* *$ & -0.960 & $* *$ & - & - & -0.954 & $* *$ & & $* *$ & & $*$ & 0.941 & $* *$ & & $*$ & 0.834 & $*$ & -0.971 & $* *$ \\
\hline & 0.960 & $* *$ & 0.880 & * & -0.907 & $*$ & - & - & 0.781 & - & 0.730 & - & & * & 0.731 & - & -0.729 & - & 0.920 & ** \\
\hline 年 & & - & -0.653 & - & 0.774 & - & 0.897 & $*$ & - & - & 0.953 & * & & $* * *$ & & * & -0.931 & ** & 0.918 & ** \\
\hline $\begin{array}{l}\text { Spike } \\
\text { per s }\end{array}$ & -0.612 & - & -0.489 & - & 0.606 & - & -0.602 & - & 0.663 & - & - & - & -0.984 & $* *$ & 0.768 & - & -0.861 & * & 0.898 & * \\
\hline $\begin{array}{l}\text { Kernels } \\
\text { per } \\
\text { snikelet }\end{array}$ & -0.126 & - & -0.293 & - & 0.178 & - & -0.105 & - & -0.136 & - & -0.665 & - & - & - & & $*$ & 0.881 & $*$ & -0.955 & ** \\
\hline $\begin{array}{l}\text { Fertile } \\
\text { tillering }\end{array}$ & -0.159 & - & -0.102 & - & 0.122 & - & -0.015 & - & & - & 0.682 & - & -0.660 & - & - & - & -0.828 & * & 0.892 & * \\
\hline Plant & 0.705 & - & 0.503 & - & -0.573 & - & 0.764 & * & -0.825 & * & -0.867 & $*$ & 0.536 & - & 0.372 & - & - & - & -0.844 & * \\
\hline Spike & -0.858 & $*$ & -0.787 & - & 0.774 & - & -0.760 & - & 0.625 & - & 0.862 & $*$ & -0.331 & - & 0.585 & - & -0.810 & - & - & - \\
\hline
\end{tabular}

${ }^{*}$ Significant at 0.05 probability level. ${ }^{* *}$ Significant at 0.01 probability level. ${ }^{* * *}$ Significant at 0.001 probability level.

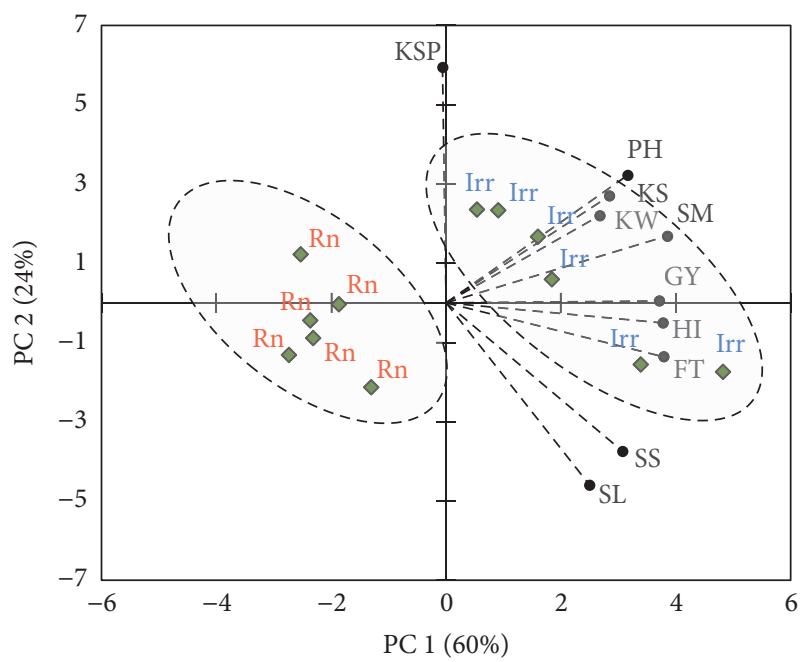

Figure 2: PCA projections on axes 1 and 2 accounting for $84 \%$ of total variance. Eigenvalues of the correlation matrix are symbolized as vectors representing traits that most influence each axis. The 12 points representing traits means for each water regime (rainfed $(\mathrm{Rn})$ and irrigated (Irr)) are plotted on the plane determined by axes 1 and 2. Grain yield (GY), spikes per $\mathrm{m}^{2}$ (SM), kernels per spike (KS), kernel weight (KW), harvest index (HI), spikelets per spike (SS), kernels per spikelet (KSP), fertile tillering (FT), plant height $(\mathrm{PH})$, and spike length (SL).

method, a variety with the lowest ASV value is the most stable. Consequently, "Ourgh" was the most stable variety followed by "Tarek." In addition, yield stability index, which combined both grain yield across environments and AMMI stability value, showed "Ourgh" and "Tarek" as the best and "Marzak" as the worst among the tested varieties.

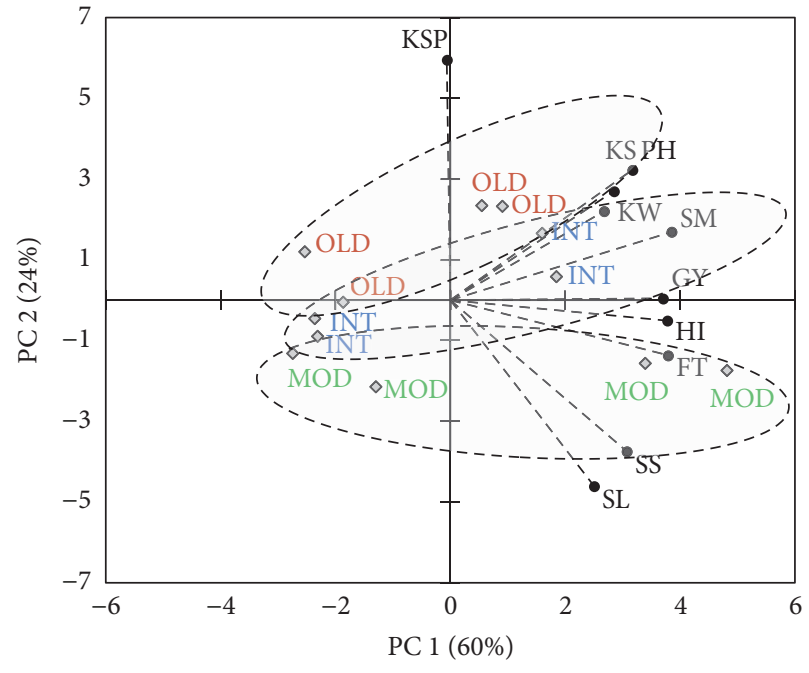

FIgURE 3: PCA projections on axes 1 and 2 accounting for $84 \%$ of total variance. Eigenvalues of the correlation matrix are symbolized as vectors representing traits that most influence each axis. The 12 points representing traits means for each period of release (old (OLD), intermediate (INT), and modern (MOD)) are plotted on the plane determined by axes 1 and 2 . Grain yield (GY), spikes per $\mathrm{m}^{2}$ (SM), kernels per spike (KS), kernel weight (KW), harvest index (HI), spikelets per spike (SS), kernels per spikelet (KSP), fertile tillering (FT), plant height (PH), and spike length (SL).

\section{Discussion}

In the Mediterranean basin, year-to-year climatic variation and abiotic factors are the main constraints to grain yield formation. The data from our experiments revealed that 


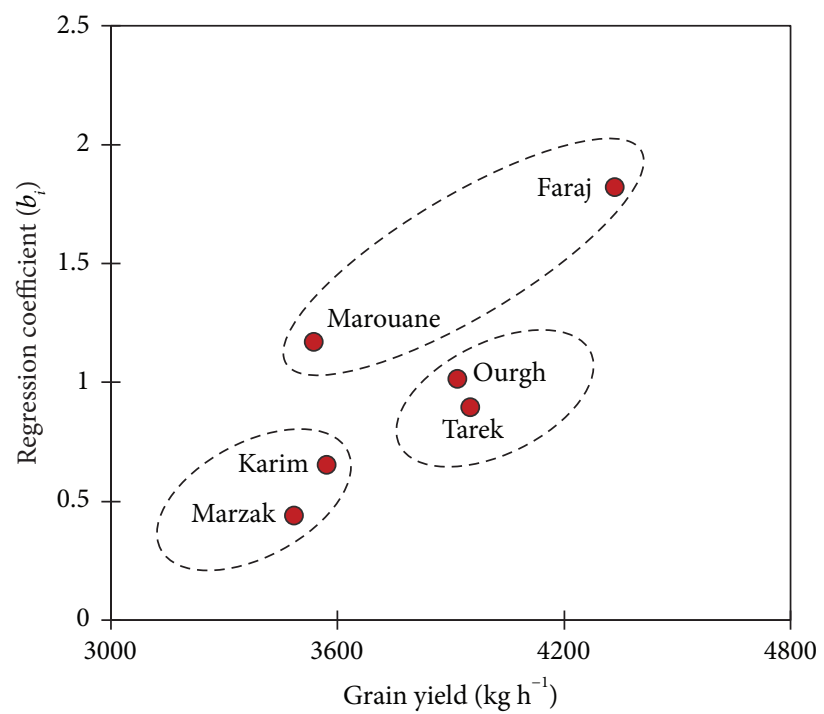

FiguRE 4: Relationship between regression coefficient $\left(b_{i}\right)$ and average grain yield of six Moroccan durum wheat varieties grown under two water regimes during three growing seasons.

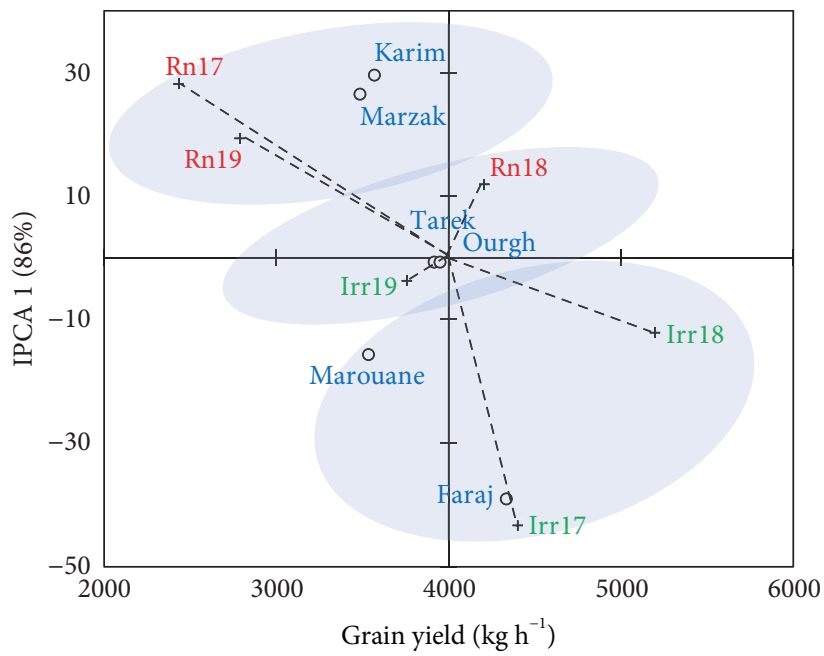

FIGURE 5: AMMI biplot for grain yield $\left(\mathrm{kg} \mathrm{h}^{-1}\right)$ of the six Moroccan durum wheat varieties evaluated in six test environments (combination of the growing season and water regime). Rn17, rainfed 2016-17; Rn18, rainfed 2017-18; Rn19, rainfed 2018-19; Irr17, irrigated 2016-17; Irr18, irrigated 2017-18; Irr19, irrigated 2018-19.

TABLE 7: Mean yield across the studies environments, AMMI stability value, and yield stability index for the studied Moroccan durum wheat varieties.

\begin{tabular}{|c|c|c|c|c|c|}
\hline Variety & $\begin{array}{l}\text { Mean grain yield across all environments (kg } \\
\qquad \mathrm{h}^{--1} \text { ) }\end{array}$ & $\begin{array}{l}\text { AMMI stability value } \\
\text { (ASV) }\end{array}$ & $\begin{array}{l}\text { Rank } \\
\text { ASV }\end{array}$ & $\begin{array}{l}\text { Yield stability index } \\
\text { (YSI) }\end{array}$ & $\begin{array}{c}\text { Rank } \\
\text { YSI }\end{array}$ \\
\hline Ourgh & 3917 & 7 & 1 & 4 & 1 \\
\hline Tarek & 3950 & 9 & 2 & 4 & 2 \\
\hline Marouane & 3536 & 156 & 3 & 8 & 4 \\
\hline Marzak & 3483 & 263 & 4 & 10 & 6 \\
\hline Karim & 3569 & 294 & 5 & 9 & 5 \\
\hline Faraj & 4333 & 387 & 6 & 7 & 3 \\
\hline
\end{tabular}

Rank YSI $=$ RASV + RY. 
grain yield and associated traits were essentially affected by water regime and growing season. In our study, the environmental effects, considering both water regimes and growing seasons, accounted for the largest percentages of variability for grain yield. This observation was reported in other studies on durum wheat under Mediterranean environments [26-30]. The nonirrigated plots had 30\% lower grain yield than irrigated ones. Pampana et al. [30] reported a significant reduction in grain yield only when waterlogging was prolonged to more than 20 days and highlighted that 40 and 60 days of waterlogging reduced grain yield by $19 \%$ and $30 \%$, respectively. Reduction in grain yield and related traits under stress are caused by pollen abortion [31], production of sterile tillers [32], and variation in resource accumulation [33]. The number of spikes per $\mathrm{m}^{2}$ was the yield component most affected by drought conditions. This trait is developed from the double ridge to anthesis, the period most sensitive to drought [34]. Giunta et al. [35] also demonstrated that severe water deficit during anthesis influenced seriously wheat grain yield by reducing the number of spikes and, therefore, decreasing plant fertility. García del Moral et al. [36] also demonstrated that water supply favored tillering and number of spikes. In addition, clear differences were observed in grain yield and related traits among the three growing seasons. The highest values were recorded in the second growing season characterized by abundant rainfall and its good distribution during crop growth.

The genetic advance in grain yield between 1984 and 2007 was $23.5 \mathrm{~kg} \mathrm{ha}^{-1}$. A similar result $\left(23.3 \mathrm{~kg} \mathrm{ha}^{-1}\right.$ per year) was reported in a study conducted on Moroccan varieties by Rharrabti and Elhani [37]. This value was also similar to the genetic yield gain of $23.6 \mathrm{~kg} \mathrm{ha}^{-1}$ per year found in Spain [23] and $19.9 \mathrm{~kg} \mathrm{ha}^{-1}$ per year reported in Italy [10]. Analogous results were also reported in similar investigations carried on bread wheat $[15,38]$. Considering each water regime separately, the genetic changes in grain yield and different traits depended on the conditions under which the durum wheat varieties were tested. The present study reported an annual genetic gain of $78 \mathrm{~kg} \mathrm{ha}^{-1}$ under irrigated conditions, and no significant change was under rainfed conditions. Similar results were reported by other researchers [21, 39-41] who worked on wheat genotypes under different climatic conditions and found a very high dependence of the genetic gain on environmental conditions. In fact, Chairi et al. [21] worked on a set of Spanish durum wheat genotypes in different sites embracing a wide range of water regimes and growing temperatures and reported that genetic gains are associated with the average mean and maximum daily temperatures of the testing site. These results indicate that there are interactions between genetic changes in grain yield and the environment in which improvement is studied. Thus, breeding effects measured on a trait in one agroecological condition are not necessarily similar in other conditions. Therefore, when similar experiments are performed by breeders, particular attention should be paid to environmental conditions.

Spikes per $\mathrm{m}^{2}$, spikelet per spike, fertile tillering, and spike length were the traits that most changed during the last three decades. Spikes per $\mathrm{m}^{2}$ exhibited a positive association with year of release under irrigated conditions, with rate of 2.2 spikes year $^{-1}$; this is similar to the increase noted for durum wheat grown under high-yielding conditions in Chile (2.6 spikes year ${ }^{-1}$ ) from 1970 to 2010 [22]. In the case of Spanish durum wheats, Chairi et al. [21] noticed a nonsignificant increase in genetic gain for spikes per $\mathrm{m}^{2}$ among cultivars released from 1980 to 2009 . The number of spikes was improved in durum wheat by increasing the capacity of the plant to revert resources to additional tillers under favorable conditions [28]. The rise in the number of spikes per $\mathrm{m}^{2}$ in our study could be explained by the significant genetic gain of fertile tillering ( $0.33 \%$ per year). Spikelet per spike significantly changed over time, increasing with year of release by 0.10 and 0.07 spikelet year $^{-1}$ under irrigated and rainfed conditions, respectively. Sanchez-Garcia et al. [40] detected also a significant association between spikelet per spike and year of release for Spanish bread wheat genotypes. In contrast, Royo et al. [42] found that the rate of genetic gain in the spikelets per spike was not significant for Italian and Spanish durum wheats obtained during the 20th century. The improvement in the number of spikelets per spike in the present work was proportional to increase in spike length (a genetic gain of $0.03 \mathrm{~cm}$ and $0.02 \mathrm{~cm}$ per year under irrigated and rainfed conditions, respectively). The greater spikes number and spikelet per spike of modern varieties suggest that Moroccan breeding program focused on improving spike size and decreasing the number of nonfertile tillers.

It is important to note that many studies have reported that plant height was reduced when comparing modern genotypes with old ones $[15,16,41-44]$. However, the varieties employed in our study were all semidwarf; therefore, plant height did not change significantly across year of release. A similar situation was reported by Chairi et al. [21] who worked on a set of 20 Spanish durum wheats fully semidwarf. In Australia, plant height declined with year of release, in bread wheats released between 1958 and 1973, but not in cultivars developed after 1973 [45].

In the present study, PCA and correlation studies showed the importance of environmental variation on the association among yield and its related traits similar to findings by García del Moral et al. [37]. Grain yield was positively associated to spike per $\mathrm{m}^{2}$, and this association becomes more important under drought conditions. Previous studies have reported that grain yield in dry Mediterranean environments is determined mainly by spikes per unit area [43, 46, 47]. García del Moral et al. [11] noted that under rainfed conditions characterized by limited tiller formation, the spike number per meter square (developed during the early stages) was the best yield component in determining grain yield. Similarly, Ercoli et al. [47] found that the increase in grain yield was due to a higher number of spikes and greater spike size and suggested that good growing conditions during the initial stages of crop development favored the development of tillers and promoted the floret fecundation. A significant correlation between grain yield and kernel weight was found under rainfed conditions, but not under irrigated ones, which is consistent with previous studies $[26,48-50]$ which reported that kernel 
weight influences grain production mostly in rainfed areas. Similarly, Bányai et al. [50] found that thousand-kernel weight proved a high repeatability under drought stress during the three years of the experiment. On the other hand, the consistent relationships between this yield component and grain yield, under rainfed conditions, would suggest that probably breeding was performed for cultivars to be grown under rainfed conditions.

Grain yield is usually used to represent the impact of the environment because it is the principal agronomic output and also because no other trait integrates interacting factors that determine plant performance [51]. In our study, the environmental effects accounted for the largest percentages of variability for grain yield. The combination of two water regimes and three growing seasons created a range of six environments. The AMMI model [8], JRA [7], and AMMI stability value [24] were employed to test grain yield stability of the studied varieties in different environments. Similarly, these stability parameters were also performed to identify the performing durum wheat $[20,52,53]$, bread wheat $[54,55]$, and barley $[56,57]$. Our results indicated that old varieties were specifically adapted to low-yielding environments and modern varieties were more adapted to high-yielding environments, while intermediates varieties are well adapted to all environments. De Vita et al. [5] worked on a set of Italian durum wheat genotypes with Rht genes released from 1975 to 2003 and highlighted that "Tiziana" and "Giusto" developed in 2001 have high-yield stability across the tested environments. In agreement with previous studies $[13,43,50,52,58,59]$, our results indicate that modern durum wheat varieties were more responsive to changes in seasons and treatments. In fact, the most stable varieties would not necessarily give the best grain yield [60]; therefore, stability per se should not be the only selection parameter. In this regard, AMMI stability value and yield stability index were used to rank varieties in terms of grain yield stability. These two stability measurements identified the intermediates varieties "Tarek" and "Ourgh" as the most stable ones.

\section{Conclusions}

Moroccan durum wheat grain yield increased significantly between 1984 and 2007 under favorable conditions, with no clear genetic advance under rainfed ones. Moreover, our results showed that the most traits measured in our trials changed significantly over time. In addition, both JRA and AMMI revealed that intermediates varieties have a wide adaptation, and old varieties were specifically adapted to water-limit environments, while modern varieties performed only to favorable environments. Moreover, the intermediates varieties "Tarek" and "Ourgh" were identified as the most stable ones.

\section{Data Availability}

The data used to support the findings of this study are available from the corresponding author upon request.

\section{Conflicts of Interest}

The authors declare that there are no conflicts of interest.

\section{Acknowledgments}

The authors wish to thank Sidi Mohamed Ben Abdellah University for providing financial support for this work.

\section{References}

[1] I. N. Xynias, I. Mylonas, E. G. Korpetis et al., "Durum wheat breeding in the mediterranean region: current status and future prospects," Agronomy, vol. 10, no. 3, p. 432, 2020.

[2] C. Royo, K. Ammar, C. Alfaro, S. Dreisigacker, L. F. G. del Moral, and D. Villegas, "Effect of Ppd-1 photoperiod sensitivity genes on dry matter production and allocation in durum wheat," Field Crops Research, vol. 221, pp. 358-367, 2018.

[3] N. Nsarellah, A. Amamou, M. Taghouti, and P. Annicchiarico, "Adaptation of Moroccan durum wheat varieties from different breeding eras," Journal of Plant Breeding and Crop Science, vol. 3, no. 2, pp. 34-40, 2011.

[4] MAPMDREF, (2019). Ministère de l'Agriculture, de la Pêche Maritime, du Développement Rural et des Eaux et Forêts, Division des statistiques. (http://www.agriculture.gov.ma), Morocco.

[5] P. De Vita, A. M. Mastrangelo, L. Matteu et al., "Genetic improvement effects on yield stability in durum wheat genotypes grown in Italy," Field Crops Research, vol. 119, no. 1, pp. 68-77, 2010.

[6] A. Pedro, R. Savin, D. Z. Habash, and G. A. Slafer, "Physiological attributes associated with yield and stability in selected lines of a durum wheat population," Euphytica, vol. 180, no. 2, pp. 195-208, 2011.

[7] K. Finlay and G. Wilkinson, "The analysis of adaptation in a plant-breeding programme," Australian Journal of Agricultural Research, vol. 14, no. 6, pp. 742-754, 1963.

[8] R. W. Zobel, M. J. Wright, and H. G. Gauch, "Statistical analysis of a yield trial," Agronomy Journal, vol. 80, no. 3, pp. 388-393, 1988.

[9] Y. Rharrabti, L. F. García del Moral, D. Villegas, and C. Royo, "Durum wheat quality in Mediterranean environments," Field Crops Research, vol. 80, no. 2, pp. 141-146, 2003.

[10] P. De Vita, O. L. D. Nicosia, F. Nigro et al., "Breeding progress in morpho-physiological, agronomical and qualitative traits of durum wheat cultivars released in Italy during the 20th century," European Journal of Agronomy, vol. 26, no. 1, pp. 39-53, 2007.

[11] L. F. G. del Moral, Y. Rharrabti, S. Elhani, V. Martos, and C. Royo, "Yield formation in Mediterranean durum wheats under two contrasting water regimes based on path-coefficient analysis," Euphytica, vol. 146, no. 3, pp. 203-212, 2005.

[12] I. I. Terrile, D. J. Miralles, and F. G. González, "Fruiting efficiency in wheat (Triticum aestivum L): trait response to different growing conditions and its relation to spike dry weight at anthesis and grain weight at harvest," Field Crops Research, vol. 201, pp. 86-96, 2017.

[13] F. Álvaro, J. Isidro, D. Villegas, L. F. García del Moral, and C. Royo, "Old and modern durum wheat varieties from Italy and Spain differ in main spike components," Field Crops Research, vol. 106, no. 1, pp. 86-93, 2008. 
[14] R. Dolferus, X. Ji, and R. A. Richards, "Abiotic stress and control of grain number in cereals," Plant Science, vol. 181, no. 4, pp. 331-341, 2011.

[15] E. Beche, G. Benin, C. L. da Silva, L. B. Munaro, and J. A. Marchese, "Genetic gain in yield and changes associated with physiological traits in Brazilian wheat during the 20th century," European Journal of Agronomy, vol. 61, pp. 49-59, 2014.

[16] P. J. Lo Valvo, D. J. Miralles, and R. A. Serrago, "Genetic progress in Argentine bread wheat varieties released between 1918 and 2011: changes in physiological and numerical yield components," Field Crops Research, vol. 221, pp. 314-321, 2018.

[17] P. Vahamidis, A. J. Karamanos, and G. Economou, "Grain number determination in durum wheat as affected by drought stress: an analysis at spike and spikelet level," Annals of Applied Biology, vol. 174, no. 2, pp. 190-208, 2019.

[18] D. J. Miralles and G. A. Slafer, "Paper presented at international workshop on increasing wheat yield potential, cimmyt, obregon, Mexico, 20-24 MARCH 2006 Sink limitations to yield in wheat: how could it be reduced?" The Journal of Agricultural Science, vol. 145, no. 02, pp. 139-149, 2007.

[19] T. W. Rife, R. A. Graybosch, and J. A. Poland, "A field-based analysis of genetic improvement for grain yield in winter wheat cultivars developed in the US central plains from 1992 to 2014," Crop Science, vol. 59, no. 3, pp. 905-910, 2019.

[20] R. Mohammadi and A. Amri, "Genotype $\times$ environment interaction and genetic improvement for yield and yield stability of rainfed durum wheat in Iran," Euphytica, vol. 192, no. 2, pp. 227-249, 2013.

[21] F. Chairi, O. Vergara-Diaz, T. Vatter et al., "Post-green revolution genetic advance in durum wheat: the case of Spain," Field Crops Research, vol. 228, pp. 158-169, 2018.

[22] A. Del Pozo, I. Matus, K. Ruf, D. Castillo, A. M. Méndez-Espinoza, and M. D. Serret, "Genetic advance of durum wheat under high yielding conditions: the case of Chile," Agronomy, vol. 9, no. 8, p. 454, 2019.

[23] C. Royo, V. Martos, A. Ramdani, D. Villegas, Y. Rharrabti, and L. F. García del Moral, "Changes in yield and carbon isotope discrimination of Italian and Spanish durum wheat during the 20th century," Agronomy Journal, vol. 100, no. 2, pp. 352-360, 2008.

[24] J. L. Purchase, H. Hatting, and C. S. Van Deventer, "Genotype $\times$ environment interaction of winter wheat (Triticum aestivum L.) in South Africa: II. Stability analysis of yield performance," South African Journal of Plant and Soil, vol. 17, no. 3, pp. 101-107, 2000.

[25] De Mendiburu, F. (2017). Agricolae: Statistical Procedures for Agricultural Research. R Package Version 1.2-8. R Found. Stat. Comput. https://CRAN.R-project.org/package=agricolae (accessed 11 March 2020).

[26] Y. Rharrabti, D. Villegas, L. F. G. Del Moral, N. Aparicio, S. Elhani, and C. Royo, "Environmental and genetic determination of protein content and grain yield in durum wheat under Mediterranean conditions," Plant Breeding, vol. 120, no. 5, pp. 381-388, 2001.

[27] D. Villegas, L. F. García del Moral, Y. Rharrabti, V. Martos, and C. Royo, "Morphological traits above the flag leaf node as indicators of drought susceptibility index in durum wheat," Journal of Agronomy and Crop Science, vol. 193, no. 2, pp. 103-116, 2007.

[28] J. Subira, F. Álvaro, L. F. García del Moral, and C. Royo, "Breeding effects on the cultivarxenvironment interaction of durum wheat yield," European Journal of Agronomy, vol. 68, pp. 78-88, 2015.
[29] M. Roselló, D. Villegas, F. Álvaro et al., "Unravelling the relationship between adaptation pattern and yield formation strategies in Mediterranean durum wheat landraces," European Journal of Agronomy, vol. 107, pp. 43-52, 2019.

[30] S. Pampana, A. Masoni, and I. Arduini, "Grain yield of durum wheat as affected by waterlogging at tillering," Cereal Research Communications, vol. 44, no. 4, pp. 706-716, 2016.

[31] X. Ji, B. Shiran, J. Wan et al., "Importance of pre-anthesis anther sink strength for maintenance of grain number during reproductive stage water stress in wheat," Plant, Cell \& Environment, vol. 33, no. 6, pp. 926-942, 2010.

[32] B. L. Duggan, R. A. Richards, A. F. Van Herwaarden, and N. A. Fettell, "Agronomic evaluation of a tiller inhibition gene (tin) in wheat. I. Effect on yield, yield components, and grain protein," Australian Journal of Agricultural Research, vol. 56, no. 2, pp. 169-178, 2005.

[33] T. R. Sinclair and P. D. Jamieson, "Grain number, wheat yield, and bottling beer: an analysis," Field Crops Research, vol. 98, no. 1, pp. 60-67, 2006.

[34] L. Shpiler and A. Blum, "Heat tolerance for yield and its components in different wheat cultivars," Euphytica, vol. 51, no. 3, pp. 257-263, 1990.

[35] F. Giunta, R. Motzo, and M. Deidda, "Effect of drought on yield and yield components of durum wheat and triticale in a Mediterranean environment," Field Crops Research, vol. 33, no. 4, pp. 399-409, 1993.

[36] L. F. G. del Moral, Y. Rharrabti, D. Villegas, and C. Royo, "Evaluation of grain yield and its components in durum wheat under Mediterranean conditions," Agronomy Journal, vol. 95, no. 2, pp. 266-274, 2003.

[37] Y. Rharrabti and S. Elhani, "Using path analysis to evaluate breeding progress in grain yield and related characters of durum wheat in Morocco," International Journal of Innovation and Applied Studies, vol. 9, no. 3, p. 1224, 2014.

[38] K. A. B. Aisawi, M. P. Reynolds, R. P. Singh, and M. J. Foulkes, "The physiological basis of the genetic progress in yield potential of CIMMYT spring wheat cultivars from 1966 to 2009," Crop Science, vol. 55, no. 4, pp. 1749-1764, 2015.

[39] M. Joudi, A. Ahmadi, V. Mohammadi, A. Abbasi, and H. Mohammadi, "Genetic changes in agronomic and phenologic traits of Iranian wheat cultivars grown in different environmental conditions," Euphytica, vol. 196, no. 2, pp. 237-249, 2014.

[40] M. Sanchez-Garcia, C. Royo, N. Aparicio, J. A. -Martín-sánchez, and F. Álvaro, "Genetic improvement of bread wheat yield and associated traits in Spain during the 20th century," The Journal of Agricultural Science, vol. 151, no. 1, pp. 105-118, 2013.

[41] Y. Sun, X. Wang, N. Wang, Y. Chen, and S. Zhang, "Changes in the yield and associated photosynthetic traits of dry-land winter wheat (Triticum aestivum L.) from the 1940s to the 2010s in Shaanxi Province of China," Field Crops Research, vol. 167, pp. 1-10, 2014.

[42] C. Royo, F. Alvaro, V. Martos et al., "Genetic changes in durum wheat yield components and associated traits in Italian and Spanish varieties during the 20th century," Euphytica, vol. 155, no. 1-2, pp. 259-270, 2007.

[43] A. Del Pozo, I. Matus, M. D. Serret, and J. L. Araus, "Agronomic and physiological traits associated with breeding advances of wheat under high-productive Mediterranean conditions. The case of Chile," Environmental and Experimental Botany, vol. 103, pp. 180-189, 2014.

[44] Y. Yao, L. Lv, L. Zhang et al., "Genetic gains in grain yield and physiological traits of winter wheat in Hebei Province of 
China, from 1964 to 2007," Field Crops Research, vol. 239, pp. 114-123, 2019.

[45] V. O. Sadras and C. Lawson, "Genetic gain in yield and associated changes in phenotype, trait plasticity and competitive ability of South Australian wheat varieties released between 1958 and 2007," Crop and Pasture Science, vol. 62, no. 7, pp. 533-549, 2011.

[46] M. Moragues, L. F. G. del Moral, M. Moralejo, and C. Royo, "Yield formation strategies of durum wheat landraces with distinct pattern of dispersal within the Mediterranean basin I: yield components," Field Crops Research, vol. 95, no. 2-3, pp. 194-205, 2006.

[47] L. Ercoli, A. Masoni, S. Pampana, M. Mariotti, and I. Arduini, "As durum wheat productivity is affected by nitrogen fertilisation management in Central Italy," European Journal of Agronomy, vol. 44, pp. 38-45, 2013.

[48] S. Elhani, N. Aparicio, Y. Rharrabti, and J. L. Araus, "Comparative performance of carbon isotope discrimination and canopy temperature depression as predictors of genotype differences in durum wheat yield in Spain," Australian Journal of Agricultural Research, vol. 53, no. 5, pp. 561--569, 2002.

[49] A. Nouri-Ganbalani, G. Nouri-Ganbalani, and D. Hassanpanah, "Effects of drought stress condition on the yield and yield components of advanced wheat genotypes in Ardabil, Iran," Journal of Food, Agriculture \& Environment, vol. 7, no. 3/4, pp. 228-234, 2009.

[50] J. Bányai, T. Kiss, S. A. Gizaw et al., "Identification of superior spring durum wheat genotypes under irrigated and rain-fed conditions," Cereal Research Communications, vol. 48, no. 3, pp. 355-364, 2020.

[51] G. H. Freeman and J. M. Perkins, "Environmental and genotype-environmental components of variability VIII. Relations between genotypes grown in different environments and measures of these environments," Heredity, vol. 27, no. 1, pp. 15-23, 1971.

[52] L. Haddad, H. Bouzerzour, A. Benmahammed et al., "Analysis of genotypex environment interaction for grain yield in early and late sowing date on durum wheat (Triticum durum Desf.) genotypes," Jordan Journal of Biological Sciences, vol. 9, pp. 139-146, 2016.

[53] A. Iannucci, P. Codianni, and P. Codianni, "Effects of conventional and organic farming systems on bio-agronomic and quality traits of durum wheat under Mediterranean conditions," Australian Journal of Crop Science, vol. 10, no. 8, p. 1083, 2016.

[54] C. Singh, A. Gupta, V. Gupta et al., "Genotype x environment interaction analysis of multi-environment wheat trials in India using AMMI and GGE biplot models," Crop Breeding and Applied Biotechnology, vol. 19, no. 3, pp. 309-318, 2019.

[55] Z. Thungo, H. Shimelis, A. Odindo, and J. Mashilo, "Genotype-by-environment effects on grain quality among heat and drought tolerant bread wheat (Triticum aestivum L.) genotypes," Journal of Plant Interactions, vol. 15, no. 1, pp. 83-92, 2020.

[56] B. Vaezi, A. Pour-Aboughadareh, R. Mohammadi et al., "GGE biplot and AMMI analysis of barley yield performance in Iran," Cereal Research Communications, vol. 45, no. 3, pp. 500-511, 2017.

[57] J. Bocianowski, T. Warzecha, K. Nowosad, and R. Bathelt, "Genotype by environment interaction using AMMI model and estimation of additive and epistasis gene effects for 1000-kernel weight in spring barley (Hordeum vulgare L.)," Journal of Applied Genetics, vol. 60, no. 2, pp. 127-135, 2019.
[58] H. Fufa, P. S. Baenziger, B. S. Beecher, R. A. Graybosch, K. M. Eskridge, and L. A. Nelson, "Genetic improvement trends in agronomic performances and end-use quality characteristics among hard red winter wheat cultivars in Nebraska," Euphytica, vol. 144, no. 1-2, pp. 187-198, 2005.

[59] S. Pampana, M. Mariotti, L. Ercoli, and A. Masoni, "Remobilization of dry matter, nitrogen and phosphorus in durum wheat as affected by genotype and environment," Italian Journal of Agronomy, vol. 2, no. 3, pp. 303-314, 2007.

[60] R. Mohammadi and A. Amri, "Comparison of parametric and non-parametric methods for selecting stable and adapted durum wheat genotypes in variable environments," Euphytica, vol. 159, no. 3, pp. 419-432, 2008. 